\title{
Optotype acuity and re-operation rate affer unilateral cataract surgery during the first 6 months of life with or without IOL implantation
}

\author{
S R Lambert, M Lynn, C Drews-Botsch, L DuBois, D A Plager, N B Medow, M E Wilson, E G Buckley
}

Aims: To compare optotype acuities and re-operation rates in children corrected with a contact lens (CL) compared with an intraocular lens (IOL) following unilateral cataract extraction during infancy in a non-randomised, retrospective case series.

Methods: 25 infants with a unilateral congenital cataract underwent cataract surgery with ( $\mathrm{OL}$ group, $\mathrm{n}=12$ ) or without ( $\mathrm{CL}$ group, $n=13$ ) IOL implantation when $<7$ months of age. Optotype acuities were assessed in 19 of these children at a mean age of 4.3 years (range 3.3-5.5 years). The number of re-operations were assessed in 21 children. Results: The visual acuity results were similar in the two treatment groups $(p=0.99)$; however, two of the four $(50 \%)$ children in the $1 O L$ group compared with two of the seven (28\%) children in the $\mathrm{CL}$ group undergoing surgery during the first 6 weeks of life had 20/40 or better visual acuity. The children in the $\mathrm{OL}$ group had more re-operations than the children in the $\mathrm{CL}$ group (mean 1.1 v 0.36). Most of the reoperations in the $\mathrm{IOL}$ group were membranectomies performed during the first year of life (median 8.0 months) whereas all of the re-operations in the $\mathrm{CL}$ group were the implantation of a secondary IOL later in childhood (mean 2.2 years).

Conclusion: Optotype acuities were similar for the children corrected with a CL compared with IOL, while the children in the $\mathrm{IOL}$ group underwent more re-operations

l ntraocular lenses (IOLs) have become the most commonly used means of optically correcting aphakia during childhood, but their implantation during infancy remains controversial because of the increased re-operation rate and large myopic shift that has been reported after their use during infancy. ${ }^{1-5}$ In an earlier study, we reported a smaller interocular difference in grating acuity in a cohort of children with a unilateral congenital cataract if an IOL was implanted at the time of cataract surgery, despite an increased short term re-operation rate in these children. ${ }^{6}$ We now report the optotype acuities and re-operation rate after a longer follow up in this same cohort of children.

\section{SUBJECTS AND METHODS \\ Subjects}

In 1999, 25 infants, from five participating centres, were enrolled in the study. The children were all born in 1997 or 1998 with a dense, unilateral congenital cataract that was extracted before the child was 7 months of age. Exclusion criteria included persistent fetal vasculature (PFV) stretching the ciliary processes or causing traction of the retina, microphthalmia (corneal diameter $<9 \mathrm{~mm}$ ), uveitis, prematurity (age $<36$ gestational weeks), retinal or optic nerve disease, ocular hypertension (intraocular pressure $>21 \mathrm{~mm} \mathrm{Hg}$ ), previous intraocular surgery, abnormalities in the fellow eye, and syndromes know to be associated with mental retardation. Parents had been given the option of having the aphakic eye corrected with a contact lens (CL) or an IOL. All parents choosing an IOL signed an informed consent form that was approved by the institutional review board at each centre. Because a CL correction was considered to be the standard of care for infants after cataract surgery, parents who chose a CL correction did not sign an informed consent form before surgery.

\section{Surgical procedures}

Cataract surgery was performed as has been previously described. ${ }^{6}$ Six infants received AcrySof IOLs (Alcon Surgical, Fort Worth, TX, USA; MA30, $\mathrm{n}=4 ;$ MA60, $\mathrm{n}=2$ ) and six received poly(methylmethacrylate) IOLs (Pharmacia, Columbus, OH, USA; 811A, $\mathrm{n}=4$; 912, $\mathrm{n}=1 ; 812 \mathrm{~B}, \mathrm{n}=1$ ). The eyes were undercorrected by 6-10 D in anticipation of a future myopic shift. The power of the IOLs implanted ranged from $24 \mathrm{D}$ to $29 \mathrm{D}$ (mean $27 \mathrm{D})$. Children not undergoing primary IOL implantation were optically corrected either with a rigid gas permeable or a Silsoft CL. Both the aphakic and pseudophakic eyes were overcorrected by $1.5-3.0 \mathrm{D}$ initially to provide a near point correction. In early childhood, bifocal spectacles were prescribed to provide both a distance and near correction. All parents were asked to patch the unaffected eye of the children for one half of their waking hours. Surgeries were performed after the initial cataract surgery to remove opacities obscuring the visual axis, to lower persistently elevated intraocular pressure $(>21 \mathrm{~mm} \mathrm{Hg})$ that could not be lowered by medical management, to explant or implant a secondary IOL, or to improve ocular alignment. All intraocular surgeries performed after cataract surgery were considered to be re-operations.

\section{Visual acuity assessment}

In July 1999, grating visual acuity was assessed by a travelling examiner using a standard set of Teller acuity cards (TAC, Vistech Consultants, Dayton, OH, USA) ${ }^{6}$ on the 12 eligible patients undergoing primary IOL implantation (IOL group) and the 13 patients who were initially corrected with a CL (CL group). ${ }^{6}$ Written informed consent was obtained from the parents of all participants before the visual acuity assessment in 1999, and this approval allowed for future medical record review. In 2003, a chart review was completed on these 25 patients after the protocol was approved by the institutional review board at each centre. Standardised data collection sheets were then used to collect optotype acuity, refractive errors, and optical correction worn at their most recent visit.

Abbreviations: $\mathrm{CL}$, contact lens; $\mathrm{IOL}$, intraocular lens; PFV, persistent fetal vasculature 
Table 1 Clinical findings in $\mathrm{IOL}$ group

\begin{tabular}{|c|c|c|c|c|c|c|c|c|c|c|}
\hline \multirow{2}{*}{$\begin{array}{l}\text { Patient } \\
\text { No }\end{array}$} & \multirow{2}{*}{$\begin{array}{l}\text { Age at } \\
\text { surgery } \\
\text { (weeks) }\end{array}$} & \multirow{2}{*}{$\begin{array}{l}\text { Age at } \\
\text { optotype } \\
\text { acuity } \\
\text { testing } \\
\text { (years) }\end{array}$} & \multirow[b]{2}{*}{ Type of IOL } & \multirow{2}{*}{$\begin{array}{l}\text { IOL } \\
\text { power } \\
\text { (D) }\end{array}$} & \multirow[b]{2}{*}{ Re-operations } & \multicolumn{2}{|c|}{ Last refractive error (D) } & \multicolumn{2}{|c|}{ Optotype acuity } & \multirow[b]{2}{*}{ Patching } \\
\hline & & & & & & Pseudophakic & Phakic & Pseudophakic & Phakic & \\
\hline 1 & 3 & 3.3 & $\begin{array}{l}\text { Pharmacia } \\
811 \mathrm{~A}\end{array}$ & 28.0 & Trabeculectomy & +0.25 & plano & $20 / 40$ & $20 / 20$ & Fair \\
\hline 2 & 4 & 4.3 & $\begin{array}{l}\text { AcrySof } \\
\text { MA30 }\end{array}$ & 28.5 & Membranectomy & +3.50 & +1.50 & $20 / 25$ & $20 / 20$ & Good \\
\hline 3 & 4 & 3.7 & $\begin{array}{l}\text { AcrySof } \\
\text { MA30 }\end{array}$ & 24.0 & $\begin{array}{l}\text { Membranectomy } \\
\times 2\end{array}$ & -8.00 & +2.50 & $\mathrm{CF}^{*}$ & $20 / 30$ & Poor \\
\hline 4 & 5 & 4.2 & $\begin{array}{l}\text { AcrySof } \\
\text { MA30 }\end{array}$ & 29.0 & $\begin{array}{l}\text { Baerveldt implant } \\
\text { 2nd IOL IOL } \\
\text { exchange }\end{array}$ & -0.75 & plano & $\mathrm{CF}$ & $20 / 30$ & N/A \\
\hline 5 & 8 & $\begin{array}{l}\text { Lost to } \\
\text { follow up }\end{array}$ & & & & & & & & \\
\hline 6 & 11 & 5.4 & $\begin{array}{l}\text { Pharmacia } \\
811 \mathrm{~A}\end{array}$ & 27.0 & $\begin{array}{l}\text { Strabismus } \times 3 \dagger \\
\text { Membranectomy }\end{array}$ & $-1.00+1.75 \times 90$ & $+1.00+1.00 \times 90$ & $20 / 70$ & $20 / 30$ & Excellent \\
\hline 7 & 13 & 3.3 & $\begin{array}{l}\text { Pharmacia } \\
811 \mathrm{~A}\end{array}$ & 30.0 & Membranectomy & -3.50 & -0.50 & NA $\ddagger$ & NA & Poor \\
\hline 8 & 16 & 4.7 & $\begin{array}{l}\text { AcrySof } \\
\text { MA60 }\end{array}$ & 25.0 & Membranectomy & +2.75 & plano & $20 / 200$ & $20 / 20$ & Fair \\
\hline 9 & 16 & $\begin{array}{l}\text { Lost to } \\
\text { follow up }\end{array}$ & & & & & & & & \\
\hline 10 & 17 & 4.3 & $\begin{array}{l}\text { Pharmacia } \\
912\end{array}$ & 26.0 & $\begin{array}{l}\text { Strabismus } \\
\text { Membranectomy }\end{array}$ & $-5.00+1.50 \times 180$ & +1.75 & $20 / 200$ & $20 / 30$ & Good \\
\hline 11 & 19 & 4.2 & $\begin{array}{l}\text { AcrySof } \\
\text { MA30 }\end{array}$ & 26.5 & $\begin{array}{l}\text { Strabismus } \\
\text { Membranectomy }\end{array}$ & +2.00 & $+1.00+3.00 \times 96$ & $20 / 400$ & $20 / 20$ & Good \\
\hline 12 & 22 & 4.7 & $\begin{array}{l}\text { Pharmacia } \\
811 \mathrm{~A}\end{array}$ & 27.5 & Strabismus & $+0.75+1.25 \times 120$ & +1.25 & $\mathrm{CF}$ & $20 / 25$ & Poor \\
\hline
\end{tabular}

Optotype acuities were obtained using Allen pictures or Snellen letters. In addition, an assessment of patching compliance, and the dates and types of re-operations were recorded. The data sheets were then faxed to the Data Coordinating Center at Emory University for analysis.

\section{Patching}

Overall compliance with patching was qualitatively assessed by the investigator who clinically followed the child as excellent (75-100\% compliance with prescribed patching regimen), good (50-74\% compliance), fair (25-49\% compliance), and poor ( $<25 \%$ compliance).

\section{Statistical analysis}

Optotype visual acuity was categorised as 20/40 or better, $20 / 50$ to $20 / 400$, and worse than $20 / 400$ and the percentage of patients in these categories was compared between the IOL and CL groups using the Freeman-Haltman test. The percentage of patients undergoing a re-operation was compared in the two groups using Fisher's exact test.

\section{RESULTS}

The mean age at the time of cataract surgery for the infants in the IOL group was 11 weeks (range 3-22) compared with 9 weeks (range 2-21) for the infants in the CL group $(p=0.5)$ as has been previously reported.$^{6}$ The mean age at the time of the optotype acuity assessment was 4.3 (SD 0.8 ) years for the IOL group and 4.4 (SD 0.9) years for the CL group (tables 1 and 2).

Optotype acuities were available for 11 of the 13 children in the CL group and nine of the 12 children in the IOL group. Two children in the CL and IOL group were lost to follow up before optotype acuities were obtained. One child in the IOL group was not included in the visual acuity analysis because he had an exclusion criteria that should have precluded him from participating in the original study (optic nerve coloboma and macular pathology associated with

Table 2 Clinical findings in $\mathrm{CL}$ group

\begin{tabular}{|c|c|c|c|c|c|c|}
\hline \multirow[b]{2}{*}{ Patient No } & \multirow{2}{*}{$\begin{array}{l}\text { Age at surgery } \\
\text { (weeks) }\end{array}$} & \multirow{2}{*}{$\begin{array}{l}\text { Age of optotype acuity } \\
\text { testing (years) }\end{array}$} & \multirow[b]{2}{*}{ Re-operations } & \multicolumn{2}{|c|}{ Optotype acuity } & \multirow[b]{2}{*}{ Patching } \\
\hline & & & & Aphakic & Phakic & \\
\hline 1 & 2 & 3.5 & Strabismus & $20 / 25$ & $20 / 20$ & Excellent \\
\hline 2 & 4 & 4.8 & None & $20 / 65$ & $20 / 30$ & Good \\
\hline 3 & 4 & 4.6 & None & $20 / 70$ & $20 / 30$ & Good \\
\hline 4 & 4 & 3.4 & Strabismus, 2nd IOL & CF & $20 / 40$ & Poor \\
\hline 5 & 5 & 4.5 & Strabismus & $20 / 40$ & $20 / 20$ & Good \\
\hline 6 & 6 & 5.1 & 2nd IOL & $\mathrm{CF}$ & $20 / 25$ & Poor \\
\hline 7 & 6 & Lost to follow up & & & & \\
\hline 8 & 6 & 4.4 & Strabismus & $\mathrm{HM}$ & $20 / 30$ & Poor \\
\hline 9 & 8 & 5.0 & None & $20 / 125$ & $20 / 50$ & Excellent \\
\hline 10 & 11 & 3.7 & Strabismus, 2nd IOL & $20 / 200$ & $20 / 20$ & Excellent \\
\hline 11 & 12 & 5.2 & None & $20 / 60$ & $20 / 20$ & Excellent \\
\hline 12 & 16 & Lost to follow up & & & & \\
\hline 13 & 21 & 5.5 & Strabismus $\times 2$ 2nd IOL & $20 / 300$ & $20 / 25$ & Poor \\
\hline
\end{tabular}




\begin{tabular}{|c|c|c|}
\hline \multirow[b]{2}{*}{ Follow up visual acuity } & \multicolumn{2}{|l|}{ Treatment } \\
\hline & $\overline{C L}(\mathrm{n}=11)^{*}$ & IOL $(n=8) \dagger$ \\
\hline $\begin{array}{l}20 / 40 \text { or better } \\
20 / 50 \text { to } 20 / 400 \\
\text { Worse than } 20 / 400 \\
\text { p Value }\end{array}$ & $\begin{array}{l}2(18 \%) \\
6(55 \%) \\
3(27 \%) \\
.99\end{array}$ & $\begin{array}{l}2(25 \%) \\
4(50 \%) \\
2(25 \%)\end{array}$ \\
\hline \multicolumn{3}{|c|}{$\begin{array}{l}\text { *Two of the } 13 \mathrm{CL} \text { patients were lost to follow up. } \\
\text { tTwo of the } 12 \mathrm{IOL} \text { patients were lost to follow up. One patient was } \\
\text { delayed developmentally, but was judged to "see well" in the } \\
\text { pseudophakic eye. One patient was excluded from the analysis because } \\
\text { of abnormalities of the retina and optic nerve that antedated cataract } \\
\text { surgery. The patient should have been excluded from participating in the } \\
\text { original study. }\end{array}$} \\
\hline
\end{tabular}

\begin{tabular}{|c|c|c|}
\hline & $C L(n=11)$ & IOL $(n=10)$ \\
\hline Procedure & $\begin{array}{l}\text { No of surgeries/ } \\
\text { patients }\end{array}$ & $\begin{array}{l}\text { No of surgeries/ } \\
\text { patients }\end{array}$ \\
\hline Membranectomy & $0 / 0$ & $8 / 7$ \\
\hline Glaucoma procedure & $0 / 0$ & $2 / 2$ \\
\hline Secondary IOL or & $4 / 4$ & $2 / 1$ \\
\hline Total & $4 / 4$ & $12 / 10$ \\
\hline
\end{tabular}

PFV). An optotype acuity could not be obtained from one child in the IOL group that was delayed developmentally. The optotype acuities were similar in the two groups (table 3 ); however, two of the four $(50 \%)$ children in the IOL group compared with two of the seven $(28 \%)$ children in the CL group undergoing cataract surgery during the first 6 weeks of life had 20/40 or better visual acuity. None of the children in either treatment group had visual acuity of 20/40 or better when cataract surgery was performed after the child was 7 weeks of age or older.

At the time of follow up, all $10(100 \%)$ patients in the IOL group and four $(36 \%)$ patients in the CL group had undergone re-operations $(p=0.09)$. The children in the IOL group underwent a mean of 1.1 re-operations compared to 0.36 re-operations for the children in the CL group (table 4). Seven $(70 \%)$ children in the IOL group had an opacity removed from the pupillary space either using a pars plana incision or a limbal incision at a median age of 8 months (range 2.5-33 months). One child required a second membranectomy 2 months later because of a recurrence of the pupillary membrane. None of the children in the CL group required a membranectomy. Four $(36 \%)$ children in the CL group had a secondary IOL implanted at a mean age of 3.2 years (range 1.3-4.9 years). One child in the IOL group had a secondary piggyback IOL implanted when 2.5 years of age. ${ }^{5}$ The piggyback IOLs were then exchanged for a single
IOL when the child was 4.2 years of age. Two patients in the IOL group underwent glaucoma surgery; one patient underwent a suture trabeculotomy when 3.5 months of age and the second patient had a Baerveldt valve implanted when 6 months of age. In addition, four (40\%) children in the IOL group and six (55\%) children in the CL group underwent strabismus surgery.

\section{DISCUSSION}

We found similar optotype acuities in a retrospective review of children with unilateral congenital cataracts following cataract surgery during the first 6 months of life coupled with primary IOL implantation and CL correction. Only about 25\% of the children in either treatment group achieved 20/40 or better visual acuity; however, a higher percentage of the children undergoing primary IOL implantation during the first 6 weeks of life achieved 20/40 or better vision despite the fact that all of these children required one or more reoperations. On average, the children in the IOL group underwent 1.1 re-operations compared to only 0.36 reoperations for the children in the CL group. Most of the reoperations in the IOL group were performed during the first year of life to clear the visual axis of opacities, whereas all of the re-operations in the CL group involved the implantation of a secondary IOL later in childhood.

In previous studies, $0-38 \%$ of infants with unilateral congenital cataracts have achieved optotype acuities of 20/ 40 or better using contact lenses (table 5 ) or IOLs (table 6). Cataract surgery during the first 6 weeks of life has been shown to be associated with the best visual progress. Birch and co-workers ${ }^{7}$ reported $20 / 40$ or better visual acuity in five of eight $(62 \%)$ patients in a small prospective study of children with unilateral congenital cataracts undergoing surgery during the first 6 weeks of life. They proposed that the first 6 weeks of life may represent a precortical stage in visual development of an infant and hence surgery during this critical period may minimise the effect of unilateral visual deprivation. ${ }^{8}$ In our study, four of the 11 patients $(36 \%)$ undergoing cataract surgery during the first 6 weeks of life compared with 0 of the $10(0 \%)$ patients undergoing cataract surgery between 7 weeks and 6 months of age achieved 20/40 or better visual acuity.

While patching compliance has been reported to be a critical variable in determining the visual outcome of children with unilateral congenital cataracts following cataract surgery, ${ }^{90}$ there was not a clear correlation between patching compliance and the visual outcome in our study. Only one of the pseudophakic patients was reported to have excellent patching, and this patient only achieved a visual outcome of 20/70. The two pseudophakic patients with the best visual outcomes (patients 1 and 2) only had fair and good patching compliance. Similarly, in the CL group, only one of the four patients with excellent patching compliance achieved a visual acuity of 20/40 or better. The age of surgery correlated much better with the visual outcome than patching compliance. However, patching compliance was

Table 5 Optotype acuities for aphakic eyes of children with unilateral congenital cataracts treated with contact lenses

\begin{tabular}{|c|c|c|c|c|c|}
\hline \multirow[b]{2}{*}{ Author } & \multirow{2}{*}{$\begin{array}{l}\text { Year of } \\
\text { publication }\end{array}$} & \multirow{2}{*}{$\begin{array}{l}\text { No of } \\
\text { patients }\end{array}$} & \multicolumn{3}{|c|}{$\%$ of patients } \\
\hline & & & $\geqslant 20 / 40$ & $20 / 50-20 / 200$ & $<20 / 200$ \\
\hline Birch $^{21}$ & 1988 & 19 & $10 \%$ & $42 \%$ & $48 \%$ \\
\hline Cheng $^{22}$ & 1991 & 20 & $10 \%$ & $25 \%$ & $65 \%$ \\
\hline Brown $^{23}$ & 1999 & 13 & $38 \%$ & $31 \%$ & $31 \%$ \\
\hline Lundvall $^{24}$ & 2002 & 25 & $0 \%$ & $34 \%$ & $76 \%$ \\
\hline Present study & 2004 & 11 & $18 \%$ & $45 \%$ & $36 \%$ \\
\hline
\end{tabular}


Table 6 Optotype acuities for pseudophakic eyes of children with unilateral congenital cataracts treated with primary $\mathrm{IOL}$ implantation

\begin{tabular}{|c|c|c|c|c|c|}
\hline \multirow[b]{2}{*}{ Author } & \multirow{2}{*}{$\begin{array}{l}\text { Year of } \\
\text { publication }\end{array}$} & \multirow{2}{*}{$\begin{array}{l}\text { No of } \\
\text { patients }\end{array}$} & \multicolumn{3}{|c|}{$\%$ of patients } \\
\hline & & & $\geqslant 20 / 40$ & $20 / 50-20 / 200$ & $<20 / 200$ \\
\hline $\begin{array}{l}\text { Dahan }^{2} \\
\text { O'Keefe }^{\prime 19} \\
\text { Present study }\end{array}$ & $\begin{array}{l}1990 \\
2001 \\
2004\end{array}$ & $\begin{array}{l}3 \\
9 \\
8\end{array}$ & $\begin{array}{l}0 \\
33 \% \\
25 \%\end{array}$ & $\begin{array}{l}100 \% \\
56 \% \\
50 \%\end{array}$ & $\begin{array}{l}0 \\
11 \% \\
25 \%\end{array}$ \\
\hline
\end{tabular}

not assessed quantitatively and the patching compliance reported may have been quite different from the patching actually performed. ${ }^{11}$

More of the children undergoing primary IOL implantation required a re-operation. In our assessment of these patients in July 1999, 10 of the $12(83 \%)$ pseudophakic patients had undergone a re-operation compared with only one of the 13 (8\%) aphakic children. In our longer term follow up, all 10 $(100 \%)$ of the pseudophakic patients had undergone a reoperation compared with four of the 11 (36\%) aphakic patients. Between 1999 and 2002, three additional secondary IOL implantations were performed in the CL group and two more membranectomies and one IOL exchange in the IOL group. Two children in the IOL group and none of the children in the CL group developed glaucoma. Both cases of glaucoma were diagnosed during the first year of follow up. While no additional cases of glaucoma were diagnosed during our longer term follow up, a longer follow up is probably necessary to diagnosis all cases since it has been reported that many cases are not diagnosed until 10 years or more after cataract surgery. ${ }^{12}{ }^{13}$ The $20 \%$ incidence of glaucoma in our pseudophakic group is similar to that reported in other series of children undergoing cataract surgery and contact lens correction. ${ }^{14-17}$ While performing a primary posterior capsulotomy was probably helpful in reducing the incidence of pupillary membranes in the IOL group, ${ }^{2}{ }^{18}$ a high percentage of these children still developed this complication. Pupillary membranes presumably develop more commonly in pseudophakic eyes because the IOLs act as scaffolding for re-proliferating lens material. In addition, more lens capsule is left in pseudophakic eyes thereby increasing the number of lens epithelial cells that are available to re-proliferate. Other authors have also reported a high incidence of pupillary membranes in infants undergoing IOL implantation. ${ }^{19}{ }^{20}$ It is reassuring that no additional sight threatening complications developed in either treatment group during our longer term follow up.

This study had a number of limitations. Firstly, it is a nonrandomised retrospective analysis. Investigators may have been biased in the types of eyes or children that were offered primary IOL implantation. Only a randomised clinical trial would eliminate such a bias from the analysis. Secondly, the sample size was small, making it difficult to demonstrate a significant effect even if one existed. Thirdly, the examiners were not masked and optotype acuity was not assessed in a standardised fashion. A large randomised clinical trial, the Infant Aphakia Treatment Study, is currently under way to prospectively compare primary IOL implantation and CL correction for children undergoing unilateral cataract surgery during the first 6 months of life.

\section{ACKNOWLEDGEMENTS}

Supported in part by Emory Children's Research Center, Knight's Templar and NIH Core Grant (P30 EY06360).

\section{Authors' affiliations}

S R Lambert, L DuBois, Emory Eye Center, Atlanta, Ga, USA
M Lynn, C Drews-Botsch, Emory University School of Public Health, Atlanta, GA, USA

D A Plager, Indiana University Medical Center, Indianapolis, IN, USA N B Medow, Manhattan Eye, Ear and Throat Hospital, New York City, NY, USA

M E Wilson, Storm Eye Institute, Charleston, SC, USA

E G Buckley, Duke University Medical Center, Durham, NC, USA

Conflict of interest: None.

Correspondence to: Scott R Lambert, MD, Emory Eye Center, 1365-B Clifton Road, NE, Atlanta, GA 30322, USA; slamber@emory.edu

Accepted for publication 9 April 2004

\section{REFERENCES}

1 Lambert SR, Drack AV. Infantile cataracts. Surv Ophthalmol 1996;40:427-588; correction 41:1

2 Dahan E, Salmenson BD. Pseudophakia in children: precautions, technique, and feasibility. J Cataract Refract Surg 1990;16:75-82.

3 Dahan E, Drusedau MUH. Choice of lens and dioptric power in pediatric pseudophakia. J Cataract Refract Surg 1997;23:618-23.

4 Lambert SR, Buckley EG, Plager DA, et al. Unilateral intraocular lens implantation during the first 6 months of life. J AAPOS 1999;3:344-9.

5 Wilson ME, Peterseim MW, Englert JA, et al. Pseudophakia and polypseudophakia in the first year of life. J AAPOS 2001;5:238-45

6 Lambert SR, Lynn M, Drews-Botsch C, et al. A comparison of grating visual acuity strabismus, and re-operation outcomes among children with aphakia and pseudophakia after unilateral cataract surgery during the first six months of life. J AAPOS 2001;5:70-5.

7 Birch EE, Swanson WH, Stager DR, et al. Outcome after very early treatment of dense congenital unilateral cataract. Invest Ophthalmol Vis Sci 1993;34:3687-99.

8 Birch EE, Stager DR. The critical period for surgical treatment of dense congenital unilateral cataract. Invest Ophthalmol Vis Sci 1996;37:1532-8.

9 Moore BD. Pediatric aphakic contact lens wear: rates of successful wear. J Pediatr Ophthalmol Strabismus 1993;30:253-8.

10 Lloyd IC, Dowler JGF, Kriss A, et al. Modulation of amblyopia therapy following early surgery for unilateral congenital cataracts. Br J Ophthalmol 1995; 79:802-6.

11 Fielder AR, Irwin M, Auld R, et al. Compliance in amblyopia therapy: objective monitoring of occlusion. Br J Ophthalmol 1995;79:585-9.

12 Mills MD, Robb RM. Glaucoma following childhood cataract surgery. J Pediatr Ophthalmol Strabismus 1994;31:355-60.

13 Simon JW, Menta N, Simmons ST, et al. Glaucoma after pediatric lensectomy/vitrectomy. Ophthalmology 1991;98:670-4.

14 Parks MM, Johnson DA, Reed GW. Long-term visual results and complications in children with aphakia. A function of cataract type. Ophthalmology 1993; 100:826-41

15 Keech RV, Tongue AC, Scott WE. Complications after surgery for congenital and infantile cataracts. Am J Ophthalmol 1989;108:136-41.

16 Asrani S, Freedman, Hasselblad V, et al. Does primary intraocular lens implantation prevent "aphakic" glaucoma in children? J AAPOS 1999;3:33-9

17 Wilson ME, Bluestein EC, Wang X-H. Current trends in the use of intraocular lenses in children. J Cataract Refract Surg 1994;20:579-83.

18 BenEzra D, Cohen E. Posterior capsulectomy in pediatric cataract surgery. The necessity of a choice. Ophthalmology 1997;104:2168-74.

19 O'Keefe M, Fenton S, Lanigan B. Visual outcomes and complications of posterior chamber intraocular lens implantation in the first year of life. $J$ Cataract Refract Surg 2001;27:2006-11.

20 Plager DA, Yang S, Neely D, et al. Complications in the first year following cataract surgery with and without $I O L$ in infants and older children. J AAPOS 2002;6:9-14.

21 Birch EE, Stager DR. Prevalence of good visual acuity following surgery for congenital unilateral cataract. Arch Ophthalmol 1988;106:40-3.

22 Cheng KP, Hiles DA, Biglan AW, et al. Visual results after early surgical treatment of unilateral congenital cataracts. Ophthalmology 1991;98:903-10.

23 Brown SM, Archer S, Del Monte MA. Stereopsis and binocular vision after surgery for unilateral infantile cataract. J AAPOS 1999;3:109-13. 